\title{
THE INFLUENCE OF ANTIBIOTICS ON THE ORIGIN OF SMALL COLONIES (G VARIANTS) OF MICROCOCCUS PYOGENES VAR. AUREUS ${ }^{1}$
}

\author{
By ROBERT I. WISE AND WESLEY W. SPINK \\ (From the Department of Medicine, University of Minnesota Hospitals, and Medical School, \\ Minneapolis, Minn.)
}

(Submitted for publication June 7, 1954; accepted August 5, 1954)

In attempting to select out penicillin-resistant colonies of staphylococcus from sensitive cultures by the method of Kirby (1), small G colonies were obtained. When isolated on plates of agar, the colonies in some instances appeared so minute, that growth was detected only with the aid of magnification. A study of this phenomenon was pursued further with many cultures of staphylococcus and with different antibiotics, and minute colonies were again isolated. The small colonies reverted to the normal larger colonies when cultured in the absence of antibiotics. Since the minute colonies originated under the influence of antibiotics commonly used in the therapy of staphylococcal diseases, the possibility presented itself that these colonies might also appear in patients while undergoing treatment with antibiotics.

This report is concerned first, with a brief summary of the literature on G colonies; second, experiments relating to the in vitro conditions under which the minute colonies appeared with the different antibiotics; third, changes in virulence and resistance to the antibiotics displayed by the parent colonies, small colonies, and the reverted large colonies; fourth, the sensitivity to bacteriophage of parent colonies, $\mathrm{G}$ colonies and reverted colonies; and, lastly, the isolation of minute colonies from human patients with staphylococcal disease.

\section{REVIEW OF LITERATURE}

Small colony variants have been described for many species of bacteria. Most of the variants reported by investigators were obtained from cultures submitted to unfavorable metabolic influences, such as chemicals, antibiotics, and aging. In some instances, isolation was from patients

1 Presented at the Forty-fifth Annual Meeting of the American Society for Clinical Investigation, Atlantic City, N. J., May 4, 1953. following treatment with antibiotics. Interest in small colonies was stimulated in 1931 by Hadley, Delves, and Klimek (2), who isolated very small colonies of Shigella from broth cultures containing lithium chloride, and reported that they passed through bacteriological filters, and suggested that they were gonidial mutants and part of a normal life cycle. Prior to their report, other workers (3-8) had noted similar types of colonies.

The method of Hadley, which incorporates selective inhibitory substances in bacteriological media, has been widely used for the isolation of $\mathrm{G}$ colonies from cultures of different bacterial species. These substances include lithium chloride, barium chloride, 2-methyl-1,4-naphthoquinone, and sterile filtrates of bacterial cultures (9-23). Appearance of $\mathrm{G}$ colonies in cultures of filtrates of "transitional" colonies of Salmonella, which appeared on MacConkey agar, has also been reported (24). Small colonies of the $G$ type have been isolated, without the aid of added inhibitory substances, from old cultures of bacteria and yeasts $(12,25-37)$.

The selection of $G$ colonies with antibiotics in vitro was first described by Schnitzer, Camagni, and Buck (20) when they observed small colonies in areas where growth of staphylococci had been inhibited by a crude extract of Penicillium notatum. These minute colonies reverted to normal colonial forms when cultivated in the absence of the antibiotic. Similar observations were reported by others $(38,39)$ who used more purified preparations of penicillin. Barbour (40) noted that streptomycin caused the appearance of $G$ forms during the development of resistance in five strains of Staphylococcus pyogenes.

The primary isolation of $G$ cultures from animal or human sources is of considerable clinical interest, for little is known concerning the possible role of such bacterial variants in disease. 
Edwards (41) encountered "dwarf" colonies of Shigella equerulis, an organism associated with a disease of horses, in 25 per cent of post mortem examinations. Bliss and Long (42) observed almost invisible colonies of hemolytic streptococci which were isolated from throats of patients with upper respiratory infections. Small colonies of gonococci were isolated by Morton and Shoemaker (43) from 3 of 135 cases of gonorrhea. It was not known whether these three cases had received treatment. Morris, Sellers, and Brown (44) isolated from blood, feces, urine, and sputum small colony variants of Eberthella typhosa from 10 of many patients between 1934 and 1940. Hall and Spink (45) isolated streptomycin-resistant and streptomycin-dependent small colonies of Brucella abortus from a patient with subacute bacterial endocarditis following treatment with streptomycin. Voureka (46) obtained small colonies from urine of patients with urinary-tract infections caused by Pseudomonas and coliform organisms following treatment with chloramphenicol. Very small colonies of staphylococcus have been isolated in pure culture from closed abscesses of three patients. In the case reported by Hale (47) small colonies were isolated from the abscess, as well as from the patient's nose. One of two patients reported by Sherris (48) had never received antibiotics; the other had been treated with penicillin.

The general characteristics of $\mathrm{G}$ colonies, which have been described for many species of bacteria are similar in most instances but there have been some reports at variance with each other. The reported characteristics may be summarized briefly as follows: Colonies are translucent, sometimes opaque, do not produce pigment and vary in size from 0.02 to $1 \mathrm{~mm}$. $(9,12,18,24,27,40)$. Broth cultures exhibit slight turbidity. Stained specimens have revealed microorganisms which were described as normal and uniform, or irregular and small. The germination period has been described as 1 hour and 45 minutes to 3 hours and 50 minutes for the $\mathrm{G}$ organisms, as compared to 36 minutes for the parent organisms (27). Hemolytic, coagulating and fermentative activity is decreased. The size of the colonies is increased by cultivation in an environment of $\mathrm{CO}_{2}$ or by the use of thiamine, or dextrose and blood in the media $(12,17,47)$. Bacteriophage susceptibility between parent cultures and their G cultures is reported to be different, the same, or decreased in case of the G colony $(9,11,21,24$, 40). Cross agglutination with antisera produced with the parent cultures and with the cultures of $\mathrm{G}$ colonies is reported to occur in most cases (6, $9,12,15,26,27,30,34,41,45)$. However, some investigators $(2,3)$ report no cross agglutination and others $(11,24)$ state that antisera prepared against $G$ cultures do not agglutinate parent cultures, whereas antisera prepared against parent cultures agglutinate both parent and G cultures. Most investigators $(2,9,12,41)$ have reported the $G$ cultures to be nonvirulent; others $(18,24$, 26,32 ) report a decrease in virulence; whereas Hadley and Carapetian (15) found an increase in virulence. Heat resistance of $\mathrm{G}$ colonies is increased or decreased $(9,21,22)$. The rate of reduction of methylene blue is decreased $(27,31)$. There is a decreased catophoretic velocity (27, 31 ). The most controversial property of the $G$ organisms is the question of their passage through bacteriological filters. They have been reported by some $(2,9,15,24,25,28)$ to be filterable, but others $(12,14,16,21,26,27,30,31,33)$ have not been able to demonstrate this characteristic.

The nature and function of $G$ colonies are not known. Hadley, Delves, and Klimek (2) believed them to be part of a normal life cycle. Youmans (13) considered them to be bacteria with a temporary loss of inactivity of certain enzyme functions and a lowered rate of metabolism, brought on by an unfavorable environment. A similar view was expressed by Weinberg (17), who thought that they were biochemically deficient variants. Lindegren (49) stated that the normal G-type transformation resembled very closely a transgenation (point mutation, gene mutation) which he believed to serve as an adaptive device.

\section{MATERIALS AND METHODS}

For the selection of $\mathrm{G}$ colonies of staphylococci with antibiotics, a method was employed similar to that used by Kirby (1) in studying the action of penicillin on staphylococci. Large inocula of a broth culture of staphylococci, which had been incubated for 18 hours, were added to each of several Klett-Summerson colorimeter tubes containing $5 \mathrm{ml}$. of tryptose phosphate broth ${ }^{2}$ and

2 Difco Laboratories, Inc., Detroit, Michigan. 


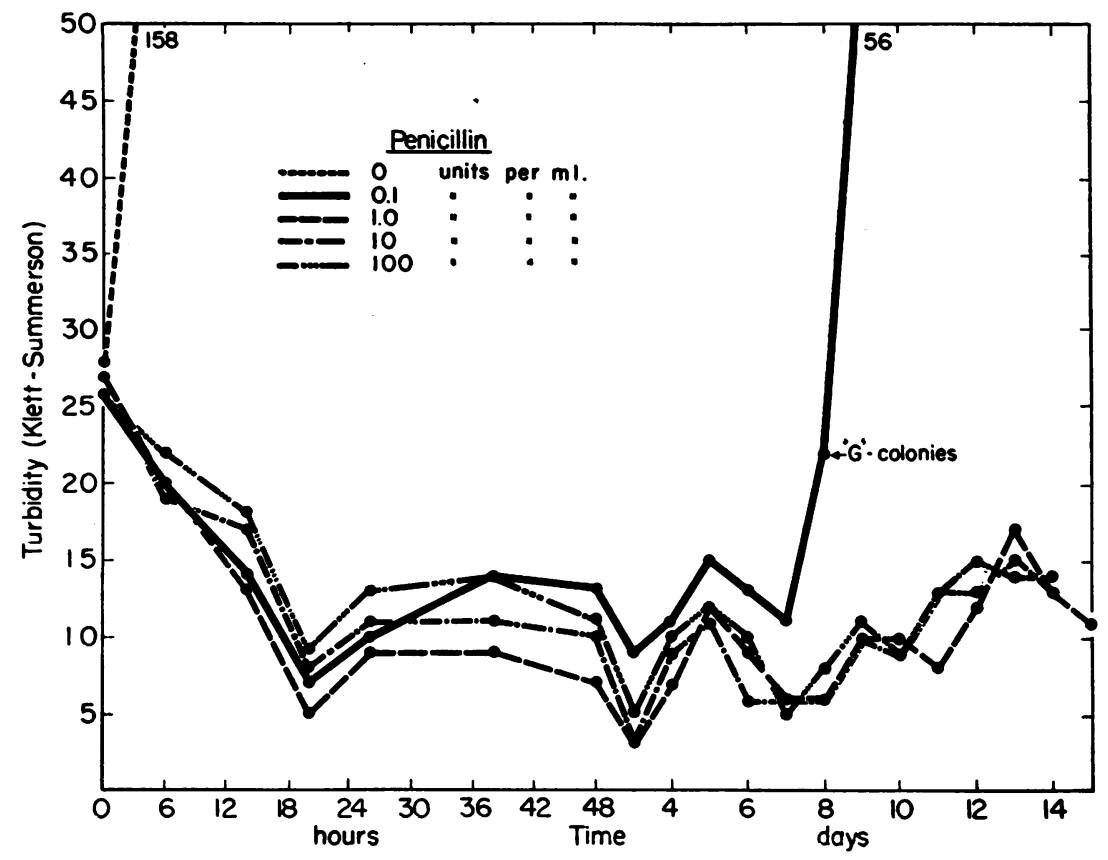

Fig. 1. Influence of Varying Concentrations of Penicillin Upon Broth Cultures of Staphylococcus

Lysis of the organisms occurred with all the concentrations, but $G$ colonies appeared only in the tube with lowest concentration of penicillin- -0.1 unit per $\mathrm{ml}$.

different concentrations of antibiotics. The antibiotics used were penicillin, streptomycin, chloramphenicol, bacitracin, carbomycin, and oxytetracyc.ine in concentrations of $0.1,1.0,10.0$, and 100.0 units or micrograms per ml., and erythromycin in concertrations of $0.25,2.5,5.0,10$, 20,40 , and 80 micrograms per $\mathrm{ml}$. The bacterial inoculum added to each tube was that amount necessary to produce an increase of 25 units in the turbidity of broth, as measured by a Klett-Summerson photoelectric colorimeter, and varied from 0.3 to $1.0 \mathrm{ml}$. in all the experiments, but a constant amount was used with each antibiotic. A series of control tubes were prepared to determine the rate of growth in the absence of antibiotics, to indicate the possibility of cortamiration of uninoculated broth containing antibiotics, and to serve as a control for turbidimetric readings. All tubes were incubated at $37^{\circ} \mathrm{C}$. The turbidity of each tube was determined at frequent intervals for 14 days. Every two days a portion of the contents of each tube was subcultured to plates of trypticase soy agar. ${ }^{3}$ After incubation the agar plates were examired with the aid of a stereoscopic microscope and selected small colonies were subcultured in broth for 24 hours. Reverted large colonies (RV) were obtained from all $G$ cultures. All cultures were maintained on agar plates in the refrigerator and in broth at minus $10^{\circ} \mathrm{C}$.

\footnotetext{
3 Baltimore Biological Products Laboratory, Baltimore,
}

\section{RESULTS}

Thirty individual strains of coagulase-positive staphylococci were studied. All strains were susceptible to low concentrations of all the antibiotics. The number of strains tested with each antibiotic was as follows: penicillin, 20; erythromycin, 10; carbomycin, 9; bacitracin, 9; streptomycin, 13 ; oxytetracycline, 8 ; and chloramphenicol, 8. Although many small colonies were selected for subculture, the majority yielded large cultures after 24 hours of incubation. However, fifteen stable $\mathrm{G}$ cultures were obtained. The number of $G$ cultures produced with each antibiotic was as follows: penicillin, 6; erythromycin, 2; carbomycin, 3 ; and bacitracin, 4 . None was isolated in the presence of streptomycin and chloramphenicol. Color changes which occurred with oxytetracycline precluded adequate determinations of turbidity, and no $\mathrm{G}$ colonies were obtained with this antibiotic. In most instances, $G$ colonies were isolated after the parent culture had been lysed by the antibiotic, and were present in only one concentration of the antibiotic.

The pattern of changes of turbidity of the cul- 


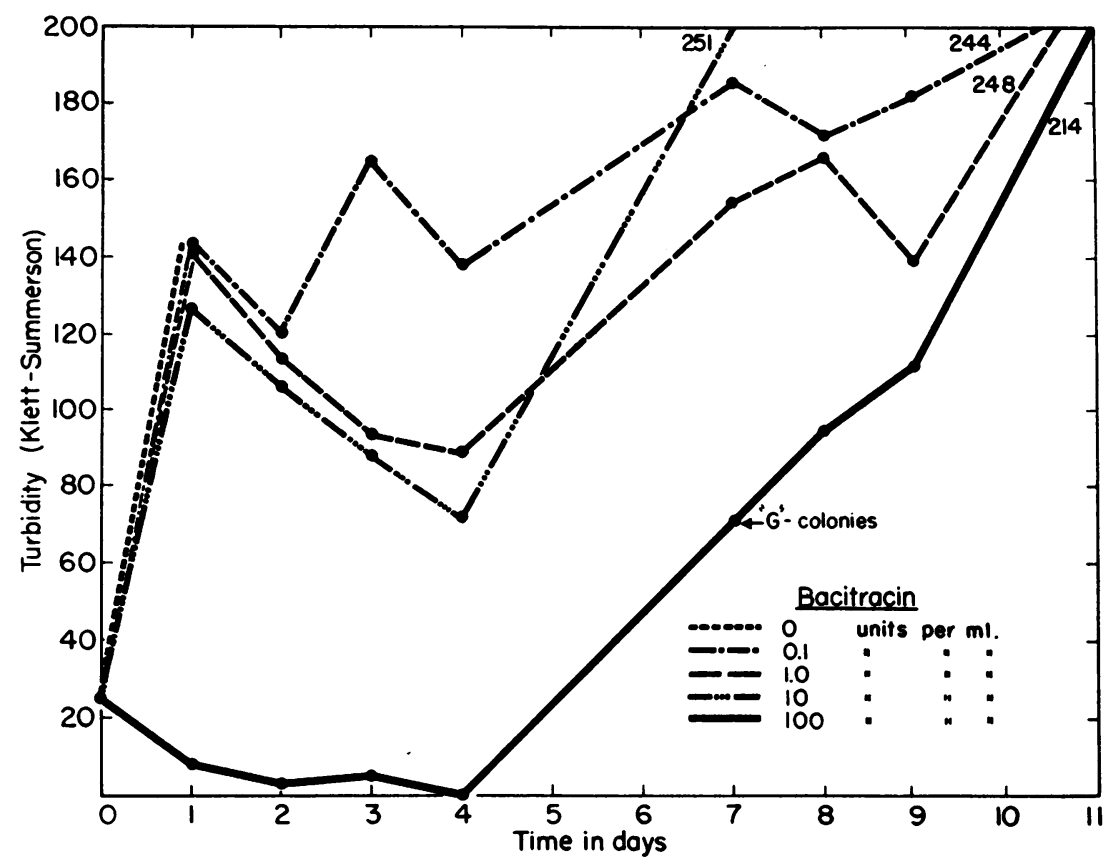

Fig. 2. Influence of Varying Concentrations of Bacitracin upon Broth Cultures of Staphylococcus

Note that lysis of the organisms occurred only with the highest concentration of bacitracin-100 units per $\mathrm{ml}$. G colonies were isolated only from the tube displaying lysis.

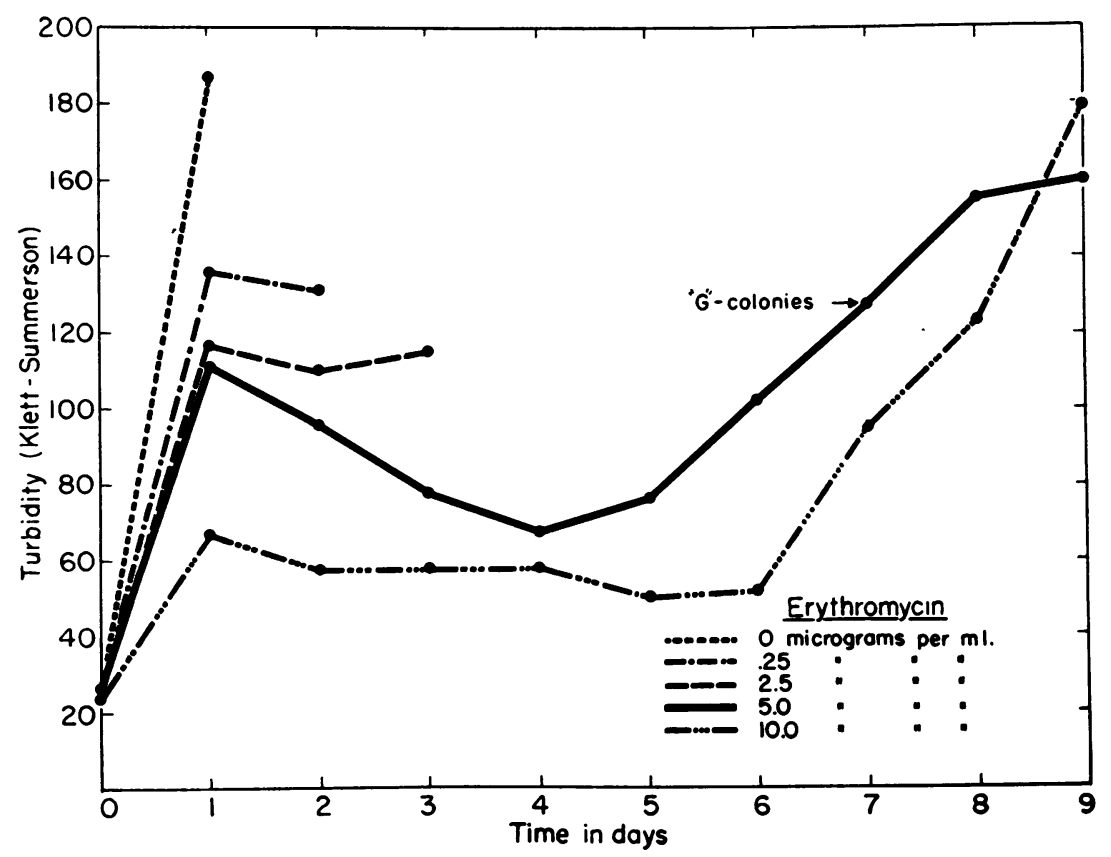

Fig. 3. Influence of Varying Concentrations of Erythromycin upon Broth Cultures of Staphylococcus

Lysis of the culture was followed by the appearance of $\mathrm{G}$ colonies in the tube having a concentration of $5 \mathrm{mcg}$. per $\mathrm{ml}$. 
tures was characteristic, though different for each antibiotic. With penicillin (Figure 1) the curves of turbidity showed lysis occurring in all tubes. In agreement with Kirby (1), this took place more completely in the presence of the lower concentrations of antibiotic. After an initial clearing of the broth because of the lysis of the staphylococci, turbidity began to increase on the eighth day in the broth containing 0.1 unit per $\mathrm{ml}$. The subculture from this tube showed hundreds of $G$ colonies.

In the presence of bacitracin (Figure 2) rapid growth of the parent culture occurred in the lower concentrations, whereas lysis took place in the tube containing 100 units per $\mathrm{ml}$. followed by the appearance of $G$ cultures in this tube on the seventh day.

In the case of erythromycin (Figure 3 ) the bacterial turbidity increased for one day with partial lysis occurring over a period of five to seven days, when small colony variants began to appear.

With carbomycin (Figure 4) G colonies were obtained on the ninth day in the tube containing 10 micrograms per $\mathrm{ml}$.
Since it had been demonstrated that $\mathrm{G}$ colonies could be selected out with different antibiotics, comparative studies were made with organisms from large colonies, $\mathrm{G}$ colonies and reverted large colonies. These investigations included a study of the general characteristics, susceptibility to bacteriophage, sensitivity to the antibiotics, production of penicillinase and virulence for small animals. Because reversion of the $G$ colonies to large colonies occurred readily, carefully controlled measures had to be employed to detect whether $\mathrm{G}$ colonies or reverted large colonies were being used in the initial inoculum. This was done by inoculating the surface of agar plates with a portion of the broth culture used as the initial inoculum. Thus, after an incubation period of 24 hours, the composition of the culture used at the beginning of an experiment could be ascertained. Similarly, since reversions could occur during the period of observation both in vitro and in vivo, subcultures of the contents of tubes and material from animals were made at the conclusion of the experiment. Only in this way could significant observations be interpreted.

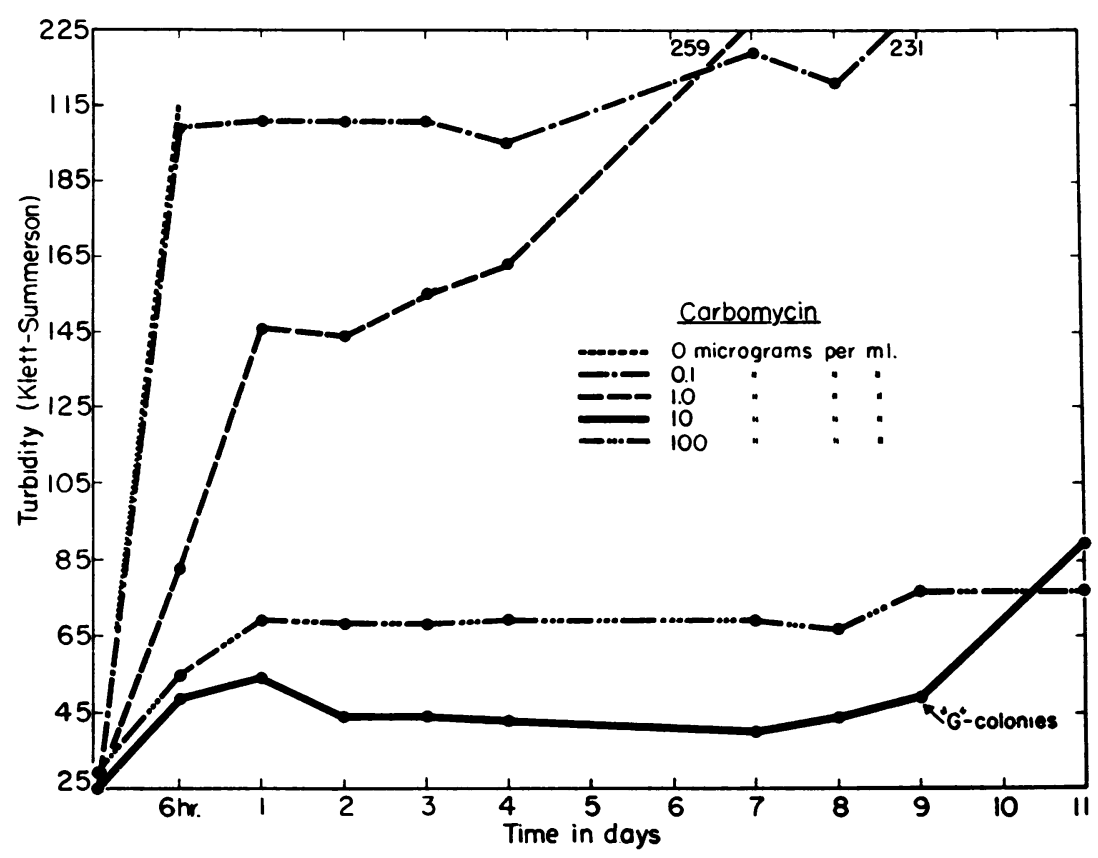

Fig. 4. Influence of Varying Concentrations of Carbomycin upon Broth Cultures of Staphylococcus

Lysis of the organisms in a concentration of $10 \mathrm{mcg}$. per $\mathrm{ml}$. was followed by the appearance of $\mathrm{G}$ colonies. 


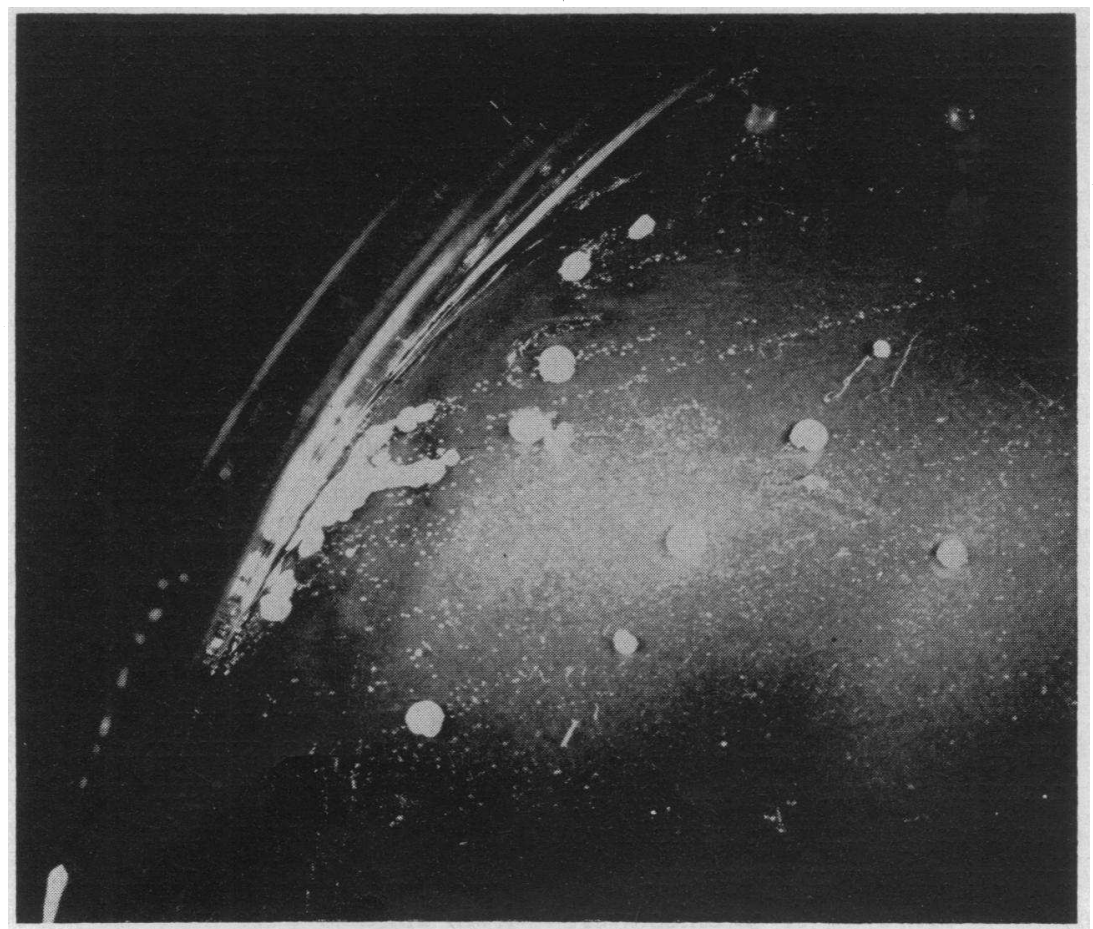

Fig. 5. Showing Comparative Size of G Colonies and Normal-Sized Large Colonies of Staphylococci

Small colonies in the presence of larger reverted colonies of normal size are demonstrated in Figure 5. The $\mathrm{G}$ colonies were translucent and nonpigmented, having a diameter of less than 0.1 $\mathrm{mm}$., and were seen with difficulty except by reflected light or with magnification. They could be easily overlooked. When cultivated in the absence of antibiotics, they reverted to colonies of normal appearance. The reversion proceeded at slow or rapid rates; some cultures reverted almost completely within 24 hours, while others remained stable for periods of a month or more. The rate of reversion was characteristic of the strain.

Contrary to the report of Youmans and Delves (19), G colonies could readily be produced from reverted cultures, and with much more success than they could be obtained from normal parent cultures. The method used for procuring $G$ cultures $\left(G_{2}\right)$ from reverted cultures $(R V)$ was the same as that employed for determining sensitivity of bacterial cultures to antibiotics with the tubedilution method (50). This consisted of adding $0.5 \mathrm{ml}$. of a 1-100 dilution of an 18-hour broth culture of the reverted strain to test tubes containing $0.5 \mathrm{ml}$. of twofold serial dilutions of the antibiotic. After incubation of 24 hours, subcultures from the tubes containing the lowest concentration of antibiotic in which no bacterial growth was visible showed the presence of $\mathrm{G}$ colonies $\left(G_{2}\right)$ in most instances.

The stained cells of $G$ cultures of staphylococci were usually indistinguishable from those of the parent cultures in regard to uniformity in size, shape, and tinctorial properties. Some G strains showed pleomorphism with large swollen cells. The $G$ cultures did not show any evidence of growth in Gladstone's synthetic medium, whereas this medium did support growth of the parent cultures (51). The G colonies were nonhemolytic. Although coagulase activity could not be demonstrated by the tube method in the usual three hours, some strains showed slight coagulase activity at 18 hours. It is possible that the coagulase activity at the end of this longer period was due to reverted cells. Penicillinase could not be demonstrated. $G$ cultures which were adapted to grow in concentrations of penicillin up to 2000 units per ml. did not manifest penicillinase activity. With reversion of the adapted penicillin-resistant $G$ strains to the large colony forms there was a 
TABLE I

Penicillin-sensitivity of reverted cultures obtained from adapted penicillin-resistant $G$ cultures

\begin{tabular}{ccc}
\hline & \multicolumn{2}{c}{$\begin{array}{c}\text { Units of penicillin per ml. } \\
\text { inhibiting growth }\end{array}$} \\
\cline { 2 - 3 } Strain & G & $\begin{array}{c}\text { Reverted } \\
\text { cultures }\end{array}$ \\
\hline No. & cultures & $<3.9$ \\
28 & 125 & 0.5 \\
28 & 500 & 1.9 \\
32 & 125 & 1.9 \\
36 & 15.6 & 0.125 \\
1 A9 & 15.6 & \\
\hline
\end{tabular}

loss of the acquired resistance (Table I). The G cultures were susceptible to the bactericidal action of human defibrinated whole blood, whereas the parent and reverted strains were resistant to this action. This was observed using a method described by Spink and Vivino (52). The cultures were incubated in blood for 24 hours at $37^{\circ}$ C. and tested for viability. The results are shown in Table II. With reversion there was a return

TABLE II

Bactericidal action of human defibrinated whole blood on parent, $G$, and reverted cultures

\begin{tabular}{lccccc}
\hline \hline & \multicolumn{5}{c}{$\begin{array}{c}\text { Bactericidal test } \\
\text { dilution of organisms }\end{array}$} \\
\cline { 2 - 6 } $\begin{array}{c}\text { Strain* } \\
\text { No. }\end{array}$ & $\mathbf{1 0}^{\mathbf{2}}$ & $\mathbf{1 0 ^ { 3 }}$ & $\mathbf{1 0 ^ { 4 }}$ & $\mathbf{1 0}^{5}$ & $10^{6}$ \\
\hline Parent 79 & + & + & + & + & 0 \\
G79 & 0 & 0 & 0 & 0 & 0 \\
RV 79 & + & + & + & + & 0 \\
\hline
\end{tabular}

* All cultures were of equal turbidity.

$++=$ growth.

to the original properties of the parent strain with respect to hemolysin, coagulase, pigmentation, and characteristics of growth.

Bacteriophage typing was carried out with the colonial variants to eliminate the possibility that the $G$ or reverted cultures were contaminants, and also, to compare their susceptibility to bacteriophage action. ${ }^{4}$ Table III shows the results of typing the parent $(P)$, small colony variant $(G)$ and reverted strains (RV) of strain 79 , which had been treated with penicillin, and strain 12 , which had been treated with erythromycin. Of 11 sets of cultures studied (a total of 33 strains), three sets (9 strains) were nontypeable. Eight sets consisting of 24 strains were typeable. Most of the $G$ cultures showed no lysis with the diluted bacteriophages which were effective for the parent and reverted strains, but required undiluted bacteriophage for the demonstration of lysis. It is significant that sensitivity to at least one bacteriophage was retained by the $G$ form, and that reversion was accompanied by a return to a lytic pattern comparable or identical with that of the parent strain. Thus, in the process of comparing the variants, there was no evidence of contamination of the cultures.

In an attempt to obtain more information concerning the selective action of penicillin for $G$ colonies, a comparison of the penicillin-sensitivity of the related variants was made using the tubedilution technique. Fifteen strains of $G$ cultures were isolated from one parent and compared to their 15 reverted strains and duplicate cultures of the parent. Results showed growth of the parent strain to be inhibited by 0.06 units per $\mathrm{ml}$.; the $\mathrm{G}$ cultures were inhibited in a range from 0.1 to 0.5 units per $\mathrm{ml}$. and the reverted cultures from 0.06 to 0.12 . This indicates that the G cultures were two to eightfold more resistant than the parent strain, and on reversion there was a return to a sensitivity similar to that of the parent,

\footnotetext{
4 Bacteriophage studies were performed with the cooperation of Dr. John Blair, Hospital for Joint Diseases, New York.
}

TABLE III

Comparative results of typing variants of two strains of staphylococcus with bacteriophages *

\begin{tabular}{|c|c|c|c|c|c|c|c|c|}
\hline \multirow{2}{*}{\begin{tabular}{l}
\multicolumn{1}{c}{ Source of culture } \\
Parent-A 79 \\
G colonies-G 79 \\
Reverted colonies - RV 79
\end{tabular}} & \multicolumn{8}{|c|}{ Bacteriophages producing lysis } \\
\hline & $\begin{array}{l}7 \\
7\end{array}$ & $42 \mathrm{C}$ & $\begin{array}{l}42 \mathrm{D} \\
42 \mathrm{D} \\
42 \mathrm{D}\end{array}$ & $47 \mathrm{~B}$ & $47 \mathrm{C}$ & $\begin{array}{l}53 \\
53\end{array}$ & $\begin{array}{l}55 \\
55\end{array}$ & $\begin{array}{l}52 \mathrm{~A} \\
52 \mathrm{~A}\end{array}$ \\
\hline $\begin{array}{l}\text { Parent-12 E } \\
\text { G colonies-G 12E } \\
\text { Reverted colonies-RV 12E }\end{array}$ & $\begin{array}{l}42 B \\
42 B \\
42 B\end{array}$ & $\begin{array}{l}47 \mathrm{C} \\
47 \mathrm{C}\end{array}$ & & & & & & \\
\hline
\end{tabular}

* The parent culture of strain 79 had been treated with penicillin, and that of strain 12 with erythromycin. 
which confirms the observations of others (20, 38 ). On the other hand, Hale (21) reported that the $G$ colony was four times more sensitive to penicillin than the parent strain. Sensitivity of related variants in which the $G$ culture had been selected with penicillin showed no significant differences in sensitivity to chlortetracycline. In comparing related variants in similar studies with erythromycin, carbomycin, and bacitracin, there was observed a two to threefold increase in resistance of the $G$ cultures over the parent strains ; however, on reversion a decrease in resistance could not be adequately demonstrated since, as indicated previously, the reverted strains produced many $G$ colonies when placed in the antibiotics.

Comparative virulence studies with related variants were carried out by injecting the strains intradermally into rabbits and noting the skin reactions, and intravenously into mice and observing the lethal effect (53). For these studies all cultures were incubated 24 hours in tryptose phosphate broth. To standardize the inocula for injection, the parent and reverted cultures were diluted with sterile broth to a degree of turbidity equal to the turbidity of the G culture. The number of bacteria could not be determined in the
G cultures since subsurface colonies could not be readily seen with the plate method. The inoculum of the diluted parent and reverted cultures, however, contained from $200,000,000$ to $1,200,000,000$ cells per $\mathrm{ml}$. All intradermal and intravenous injections consisted of $0.25 \mathrm{ml}$.

In the rabbit the sites of intradermal injections of the G cultures were just discernible after 48 hours. But at the sites of injections of the parent and reverted strains, there were edema, erythema, and pustule formation, and after four to six days areas of necrosis appeared. The reverted strains produced necrotic reactions in the skin that were of similar or greater severity than the reaction produced by the related parent strains.

The lethal results following the intravenous inoculation of mice are charted in Figure 6 . Twenty white mice of the same age, weight, and genetic strain were injected with each culture of the related variants. At the end of 120 hours there was 100 per cent survival of mice receiving the $G$ culture. These mice continued in apparent good health for two weeks, at which time they were sacrificed and $G$ cultures were isolated from their kidneys. At the end of 24 hours the fatality rates of the "reverted" and "parent" groups were 90 per cent and 25 per cent, respectively. All mice

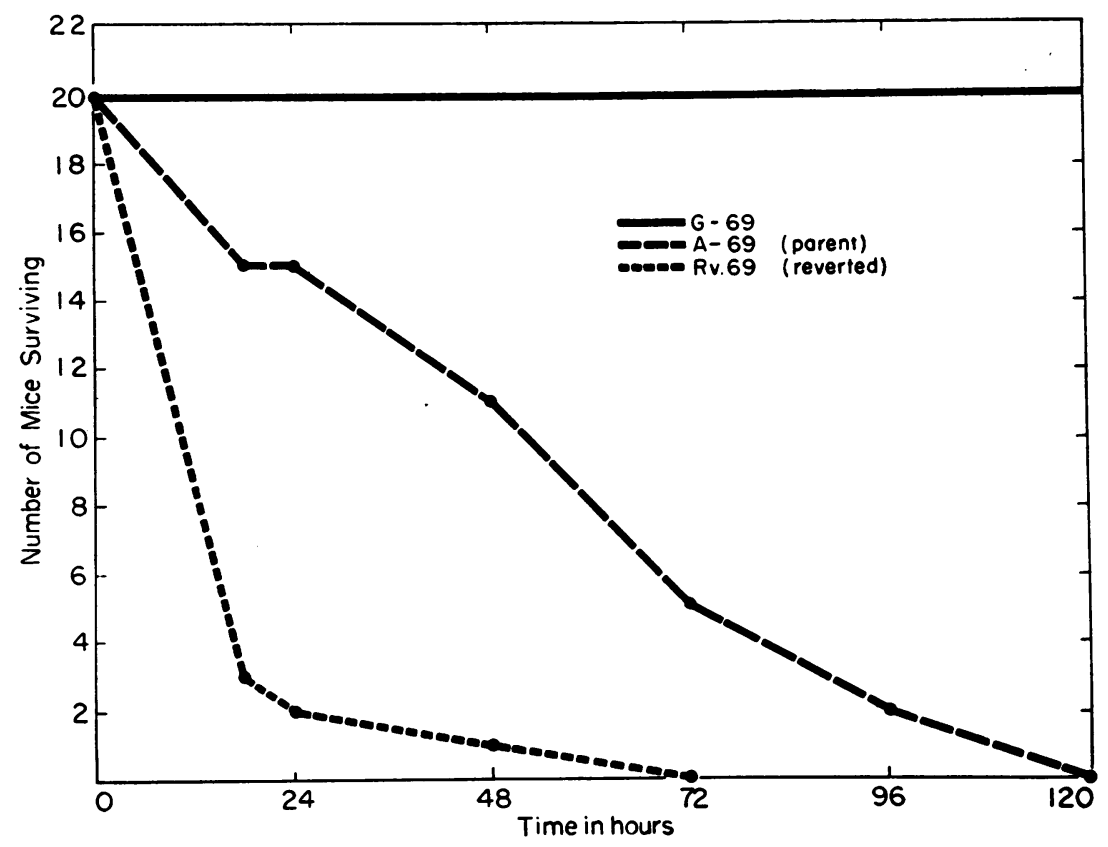

Fig. 6. Survival Curves of Mice Following the Intravenous Injection of Parent, G and Reverted Cultures of a Strain of Staphylococcus 
receiving the reverted strain were dead in 72 hours and all receiving the parent strain were dead in 120 hours. Cultures of the spleens, livers, and kidneys of mice which had been injected with the parent and reverted strains revealed staphylococci in great numbers. The outstanding features of these studies were first, the increased virulence which occurred with reversion of the avirulent small-colony variants, and second, the continued existence of the $G$ cultures in the kidneys of apparently normal mice.

The presence of $\mathrm{G}$ colonies of staphylococci in human material was investigated by examining with magnification the original cultures of approximately 500 specimens of blood, exudate, urine, and other body fluids. Ten cultures of $\mathrm{G}$ colonies were isolated from eight patients, as shown in Table IV. Seven of the patients were being

TABLE IV

Isolation of $G$ colonies of staphylococcus from human patients

\begin{tabular}{|c|c|c|}
\hline $\begin{array}{l}\text { No. of } \\
\text { culture }\end{array}$ & Source of G colonies & $\begin{array}{l}\text { Treatment received } \\
\text { by patients }\end{array}$ \\
\hline 1 & Fluid from chest cavity & \multirow{9}{*}{$\begin{array}{l}\text { Penicillin } \\
\text { Gantrisin } \\
\text { Penicillin } \\
\text { Streptomycin } \\
\text { Penicillin } \\
\text { Streptomycin } \\
\text { Chlortetracycline } \\
\text { Gantrisin } \\
\text { Chlortetracycline } \\
\text { Penicillin } \\
\text { None }\end{array}$} \\
\hline 2 & Urine & \\
\hline 3 & Throat & \\
\hline & & \\
\hline 4 & Throat & \\
\hline 5 & Urine & \\
\hline 6 & Urine & \\
\hline 7 & Blood & \\
\hline 8 & Urine & \\
\hline
\end{tabular}

treated with an antibiotic or sulfonamide at the time the isolates were made. When the first eight cultures were examined, there was no knowledge of the identity of the specimens or the history of the patient. It is interesting that cultures 3 and 4 were from the same patient. Gram stains of $G$ cultures 1 to 8 inclusive revealed Gram-positive cocci. These cultures gradually reverted to colonies of normal size. The characteristics of cultures 9 and 10 differed from the others and were obtained under the following circumstances: $\mathrm{Pa}$ tient C. C. was a 77 year old male with cystitis caused by Staphylococcus aureus, which appeared to be present in pure culture. An attempt was then made to study the production of $\mathrm{G}$ colonies in vivo in this patient. $\mathrm{He}$ was treated with erythromycin, $250 \mathrm{mg}$. every six hours. Urine was collected daily for culture, and the plates were examined carefully for $G$ colonies with the aid of magnification. There was a gradual elimination of normal staphylococcal colonies over a period of four days. On the fifth day there were two normal colonies and many microcolonies which could be seen only with magnification. These small colonies were transferred to broth and to agar. Stained smears of these colonies revealed Gram-positive pleomorphic rods with cocco-bacillary and coccoid forms similar to those described by Voureka (46), which she had isolated from urine during therapy with chloramphenicol. These colonies remained stable through many subcultures and did not revert to large colonies.

\section{DISCUSSION}

It has long been known that bacteria produce small colony variants and that these forms can be recovered more readily when the cultures are subjected to unfavorable environments. In the present studies, $G$ cultures have appeared under in vitro experimental conditions, and in patients following exposure of bacteria to antibacterial agents. Under in vitro conditions, there exists an optimum concentration of antibiotic for recovering $G$ colonies. The $G$ forms are two to eight times more resistant than are the parent cells. Therefore, the slow growing $G$ variants can be isolated most readily with concentrations of antibiotic that eliminate or inhibit growth of the normal forms, and permit the $G$ forms to reproduce. This optimum concentration falls within a narrow range. If the concentration is reduced, the normal forms reproduce rapidly and overgrow the less active $G$ forms. If the concentration of antibiotic is too great, there is inhibition or elimination of the normal parent cells, as well as the $\mathrm{G}$ forms.

The G cultures are devoid of hemolysin and coagulase activity; there is an increase in nutritional requirements; and biochemical activity is diminished. The $G$ variants have a loss of virulence and remain viable in animal tissues without producing signs of infection. Reversion to cultures of large colonies in vivo has not been proved. The small forms remain stable in the presence of antibiotics in concentrations that do not destroy 
them. When cultivated in the absence of antibiotics, $\mathrm{G}$ colonies revert to large colonies, and there is a restoration of the reproduction of hemolysin and coagulase. The reverted form is as virulent as the original parent strain, and in some cases is more virulent. The reverted strain is similar but not identical to the parent, because the reverted strain may display increased virulence, and G colonies are obtained from reverted cultures more readily than they can be selected from the parent. Bacteriophage typing of related strains proved their genetic relationship and eliminated the possibility that these cultures were contaminants.

Small colony variants have been isolated from human sources, in which the patients with one exception gave a history of therapy with antibiotics or sulfonamides. It is not unlikely that optimum concentrations of antibiotics for the survival of $\mathrm{G}$ colonies may occur in human tissues during therapy of staphylococcal infections, and under these conditions avirulent small-colony variants may be selected out, and remain undetected. Following cessation of therapy, reversion to a virulent form may occur, and relapse of the infection may ensue. Careful bacteriological studies should include a search for $G$ colonies subsequent to apparently successful treatment in patients with staphylococcal disease. Further investigations are now under way to determine how long the $G$ variants will remain in tissues and under what conditions reversion to the large virulent colonies will occur.

\section{CONCLUSIONS}

1. Small colony variants ( $G$ variants) of staphylococci were selected out with the aid of antibiotics.

2. The characteristics of the $G$ variants were studied and they are as follows: Compared to the parent strain, they have less hemolytic activity and produce less coagulase. The nutritional requirements are more demanding. The G cultures are less virulent, and remain viable in tissues of apparently normal animals. The $\mathrm{G}$ cultures were two to eightfold more resistant to the antibiotics than the parent cultures.

3. Reversion of $G$ cultures to large colonies took place when cultivated in the absence of anti- biotics. The characteristics of the reverted forms were the same as the parent cells, except the virulence of the reverted forms was increased in some instances.

4. Bacteriophage typing of the parent cells, and related $G$ forms and reverted large colonies, showed a genetic relationship, which ruled out the possibilities of contamination.

5. Cultures of $G$ colonies were obtained from human sources following treatment with antibacterial drugs.

\section{REFERENCES}

1. Kirby, W. M. M., Bacteriostatic and lytic actions of penicillin on sensitive and resistant staphylococci. J. Clin. Invest., 1945, 24, 165.

2. Hadley, P., Delves, E., and Klimek, J., The filterable forms of bacteria. I. A filterable stage in the life history of the Shiga dysentery bacillus. J. Infect. Dis., 1931, 48, 1.

3. Jacobsen, K. A., Mitteilungen über einen variablen Typhusstamm (Bacterium typhi mutabile), sowie über eine eigentumliche hemmende Wirkung des gewöhnlichen Agar, verursacht durch Autoklavierung. Centralb. f. Bakt. 1910, Abt. 1, 56, 208.

4. Eisenberg, P., Untersuchungen ïber die Variabilität der Bakterien. IV. Ueber den Variationskreis des B. prodigiosum und B. violaceum. Centralb. f. Bakt., 1914, Abt. 1, 73, 449 and 466.

5. Baerthlein, K., Ueber bakterielle Variabililät, insbesondere sogenannte Bakterienmutationen. Centralb. f. Bakt., 1918, 1, 81, 369.

6. Fürth, J., Variationsversuche mit Paratyphus $\beta$. (Weil). Ztschr. f. Immunitätsforsch u. exper. Therap., 1922, 35, 155.

7. Fürth, J., Rezeptorenanalyse und Variationsversuche mit B. Paratyphus Aertryck. Ztschr. f. Immunitätsforsch u. exper. Therap., 1922, 35, 162.

8. Friedberger, E., Ueber Bacterienvirus (kryptantigenes Virus) nach Versuchen mit Typhusvirus. Ztschr. f. Immunitätsforsch u. exper. Therap., 1927, 53, 339.

9. Hoffstadt, R. E., and Youmars, G. P., Staphylococcus aureus: Dissociation and its relation to infection and to immunity. J. Infect. Dis., 1932, 51, 216.

10. Hoffstadt, R. E., and Youmans, G. P., The genetic significance of the dissociants of Staphylococcus aureus. J. Bact., 1934, 27, 551.

11. Hoffstadt, R. E., Youmans, G. P., and Clark, W., Antigenic structure of Staphylococcus aureus and its variants. J. Bact., 1934, 27, 97.

12. Swingle, E. L., Studies on small colony variants of Staphylococcus aureus. Proc. Soc. Exper. Biol. \& Med., 1934, 31, 981. 
13. Youmans, G. P., Production of small-colony variants of Staphylococcus aureus. Proc. Soc. Exper. Biol. \& Med., 1937, 36, 94.

14. Rettger, L. F., and Gillespie, H. B., Bacterial variation, with special reference to pleomorphism and filterability. J. Bact., 1933, 26, 289.

15. Hadley, P., and Carapetian, H., A study of the infective qualities possessed by $G$ phase cultures of Bacillus typhosus. J. Bact., 1933, 25, 94.

16. Raney, M. E., and Kopeloff, N., Dissociation and filtration studies with L. acidophilus. J. Bact., 1934, 27, 45.

17. Weinberg, E. D., Vitamin requirements of dwarf colony variants of bacteria. J. Infect. Dis., 1950, 87, 299.

18. Duff, D. C. B., Dissociation in Bacillus salmonicida, with special reference to the appearance of a G form of culture. J. Bact., 1937, 34, 49.

19. Youmans, G. P., and Delves, E., The effect of inorganic salts on the production of small colony variants by Staphylococcus aureus. J. Bact., 1942. 44, 127.

20. Schnitzer, R. J., Camagni, L. J., and Buck, M., Resistance of small colony variants ( $\mathrm{G}$-forms) of a staphylococcus toward the bacteriostatic activity of penicillin. Proc. Soc. Exper. Biol. \& Med., 1943, 53, 75.

21. Hale, J. H., Studies on staphylococcus mutation: Characteristics of the "G" (gonidial) variant and factors concerned in its production. Brit. J. Exper. Path., 1947, 28, 202.

22. Colwell, C. A., Small colony variants of Escherichia coli. J. Bact., 1946, 52, 417.

23. Hoffstadt, R. E., and Almaden, P., Dissociation of Staphylococcus aureus. III. Relation of bacteriophage to the dissociation of Staphylococcus aureus. J. Infect. Dis., 1934, 54, 253.

24. Haddow, A., Small-colony variation in B. paratyphosus $B$ (Tidy) and other bacteria, with special reference to the $G$ type of Hadley. J. Infect. Dis., 1938, 63, 129.

25. Novak, M. V., and Henrici, A. T., Pleomorphic organism showing relationships between staphylococci and actinomycetes. J. Infect. Dis., 1933, 52, 253.

26. Swingle, E. L., Studies on small colony variants of Staphylococcus aureus. J. Bact., 1935, 29, 467.

27. Chinn, B. D., Characteristics of small colony variants of Shigella paradysenteriae Sonne and Staphylococcus aureus. Proc. Soc. Exper. Biol. \& Med., 1936, 34, 237.

28. Colien, F. E., A study of microbic variation in a yellow pigment-producing coccus. J. Bact., 1935, 30, 301 .

29. Dienst, R. B., A study of some of the factors promoting dissociation of Bacterium dysenteriae Sonne. J. Bact., 1933, 26, 489.
30. Koser, S. A., and Dienst, R. B., Small colony variants or $\mathrm{G}$ forms of Eberthella dysenteriae Sonne. J. Infect. Dis., 1934, 54, 131.

31. Chinn, B. D., Characteristics of small colony variants with special reference to Shigella paradysenteriae Sonne. J. Infect. Dis., 1936, 59, 137.

32. Roe, A. F., Dissociation of Cl. welchii. J. Bact., 1934, 27, 46.

33. Kopeloff, N., Dissociation and filtration of Lactobacillus acidophilus. J. Infect. Dis., 1934, 55, 368.

34. Raven, C., Dissociation of the gonococcus. J. Infect. Dis., 1934, 55, 328.

35. Raven, C., Dissociation of the gonococcus. Proc. Soc. Exper. Biol. \& Med., 1934, 31, 899.

36. Fabian, F. W., and McCullough, N. B., Dissociation in yeasts. J. Bact., 1934, 27, 43.

37. Huddleson, I. F., and Baltzer, B., The characteristics and dissociation pattern of type $\mathrm{G}$ (micro-colony type) of Brucella abortus in Studies in Brucellosis, III. A series of five papers. East Lansing, Michigan State College, Agr. Exp. Sta., Department of Bacteriology and Public Health, 1952, p. 64.

38. Youmans, G. P., Williston, E. H., and Simon, M., Production of small colony variants of Staphlococcus aureus by the action of penicillin. Proc. Soc. Exper. Biol. \& Med., 1945, 58, 56.

39. Eriksen, K., Studies on induced resistance to penicillin in staphylococci. Acta path. et microbiol. Scandinav., 1946, 23, 284.

40. Barbour, R. G. H., Small colony variants ("G" forms) produced by Staph. pyogenes during the development of resistance to streptomycin. Australian J. Exper. Biol. \& M. Sc., 1950, 28, 411.

41. Edwards, P. R., Studies on Shigella equirulis. III. The occurrence of dwarf colony variants. Kentucky Agr. Exp. Sta. Bull., 1931, No. 320, 320.

42. Bliss, E. A., and Long, P. H., Studies on minute hemolytic streptococci. I. The cultural characteristics of minute hemolytic streptococci. J. Bact., 1934, 27, 105.

43. Morton, H. E., and Shoemaker, J., The identification of Neisseria gonorrhoeae by means of bacterial variation and the detection of small colony forms in clinical material. J. Bact., 1945, 50, 585.

44. Morris, J. F., Sellers, T. F., and Brown, A. W., The primary isolation of small colony strains of Eberthella typhosa from blood, feces, urine, and sputum. J. Infect. Dis., 1941, 68, 117.

45. Hall, W. H., and Spink, W. W., In vitro sensitivity of Brucella to streptomycin: Development of resistance during streptomycin treatment. Proc. Soc. Exper. Biol. \& Med., 1947, 64, 403.

46. Voureka, A., Bacterial variants in patients treated with chloramphenicol. Lancet, 1951, i, 27.

47. Hale, J. H., Studies on staphylococcus mutation: A naturally occurring "G" gonidial variant and its 
carbon dioxide requirements. Brit. J. Exper. Path., 1951, 32, 307.

48. Sherris, J. C., Two small colony variants of Staph. aureus isolated in pure culture from closed infected lesions and their carbon dioxide requirements. J. Clin. Path., 1952, 5, 354.

49. Lindegren, C. C., Genetical studies of bacteria. III. Origin of G-type colonies by transgenation. Zentralbl. f. Bakt., II, 1935, 93, 389.

50. Waisbren, B. A., Carr, C., and Dunnette, J., The tube dilution method of determining bacterial sen- sitivity to antibiotics. Am. J. Clin. Path., 1951, 21, 884.

51. Gladstone, G. P., The nutrition of Staphylococcus aureus: nitrogen requirements. Brit. J. Exper. Path., 1937, 18, 322.

52. Spink, W. W., and Vivino, J. J., The coagulase test for staphylococci and its correlation with the resistance of the organisms to the bactericidal action of human blood. J. Clin. Invest., 1942, 21, 353.

53. Gorrill, R. H., Experimental staphylococcal infections in mice. Brit. J. Exper. Path., 1951, 32, 151. 